\title{
Legal Review In Structuring And Normalization Of Rivers As An Effort To Mitigate Flooding In The City Of Banjarmasin
}

\author{
Muhammad Hadin Muhjad ${ }^{1}$, Muhammad Erfa Redhani ${ }^{2}$, Ichsan Anwary ${ }^{3}$ \\ Ahmad Fikri Hadin ${ }^{4}$ \\ 1,2,3,4 Faculty of Law, Lambung Mangkurat University \\ Jl. Brigjen H. Hasan Basry Kayu Tangi, Banjarmasin, Indonesia \\ * Corresponding author: \\ Email: mhmuhjad@ulm.ac.id
}

\begin{abstract}
.
The rivers and canals in Banjarmasin need to be reorganized to restore the rivers and canals to be able to function. Various legal policies have been taken by Banjarmasin Government, from issuing regulations on rivers to making policies to establish a River Normalization Task Force. This research is aimed to analyze the Banjarmasin government's regional regulations that regulate the rivers and rivers layout, as well as the effectiveness of the legal policy taken by the government as mitigation of the flood problems Banjarmasin faces. This study uses an interdisciplinary legal research method (socio-legal methodology); where the law (in this case the statutory text) is not only interpreted as an object of value-free study but the law is interpreted as an object that is rich in values (including non-legal values).Based on the geographical condition of Banjarmasin, rivers and canals should be very important for Banjarmasin as a way to avoid flooding. Therefore, it is necessary to arrange rivers and canals in Banjarmasin comprehensively and this arrangement cannot be done only partially. The river arrangement includes regulatory, institutional, and community development aspects in the vicinity. The development of the city of Banjarmasin from the point of view of city development must start from the rivers.
\end{abstract}

Keywords: Normalization, rivers, canals, layout, flood.

\section{INTRODUCTION}

In many countries, the issues related to the rivers and the environment are not the same. In general, eighty percent of the world's population is at risk of water scarcity because human activities in developed and developing countries threaten the world's freshwater systems and their biodiversity (Guardian). One of the main issues in international relations today is the issue of the security of natural resources, one of which is water. Water is now increasingly seen as a strategic resource that must be secured. In this context, water security and international relations are often intertwined. Regarding water security, this can trigger cooperation between countries or even trigger conflict[i]. Still related to water security, from large river areas to small rivers, Southeast Asia is home to these waters and rivers. The most famous river in Southeast Asia is the Mekong River, which extends and crosses across five countries and is the 12th longest river in the world. The Mekong River itself is a source of drinking water, a source of food (fish), as the water needed for agrarian purposes, and fulfills the livelihoods of millions of people. 
However, despite being a source of life for humans in five countries, many do not realize that the Mekong River is a source of garbage disposal and waste, making the Mekong River one of the dirtiest and most polluted rivers in these countries[ii]. Another serious problem faced by countries traversed by the Mekong River is the uncontrolled discharge of wastewater, industrial discharges, and how this affects agricultural life affects Asia as a whole. In addition, there is still a lot of wastewater that has not been handled. Comprehensive databases related to river problems are still not widely available and national data indicates that bad water quality is a very serious problem.Despite the myriad of environmental problems Mekong River is facing as described above, some progress could shed some light. Efforts to monitor water quality are now being stepped up and some countries already have systems that can guide other countries in the Mekong River area. The efforts of aquatic organizations such as the Mekong River Commission can help to develop policies and solutions that can be implemented by countries.

Many regulatory and economic options are being tested to control river pollution, but institutional and social challenges remain, particularly concerning growing populations and their effects on the rivers flowing through some of these countries. [iii]Unlike the case of the Mekong River above, the river problem in Banjarmasin City has its uniqueness. The main function of the river in Banjarmasin is as a raw material for drinking water, and if the river water is experiencing seawater intrusion, the drinking water supply is supplied by the district. The function of the two rivers is no less important is as drainage. This second function sometimes experiences problems as in other rivers in cities in Indonesia. As a result of the non-functioning of the river as effective drainage, during a major flood in South Kalimantan in early February 2021, Banjarmasin was inundated by water for a long time and resulting in the paralysis of social and economic activities of the city's residents. Therefore, the function of the river as drainage must be seriously considered by the Banjarmasin government.

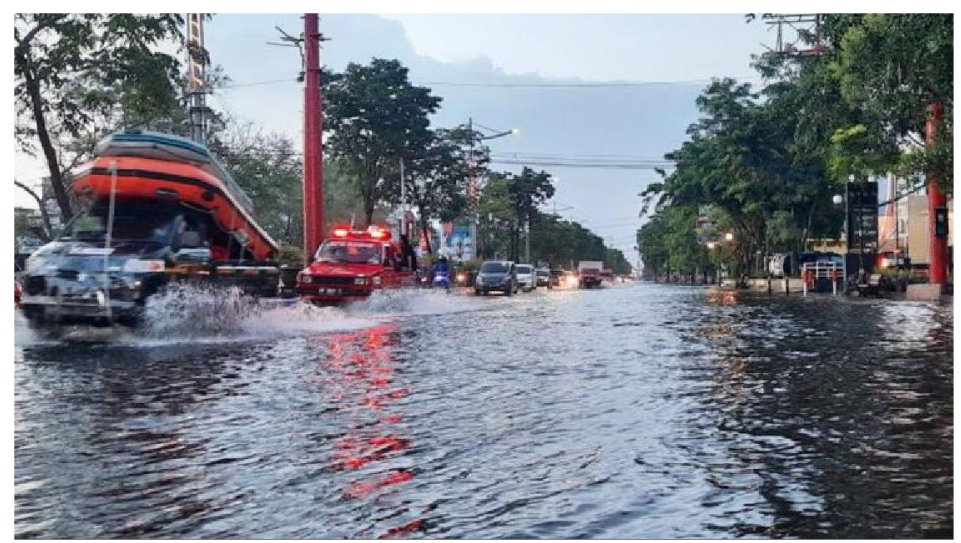

The main road in Banjarmasin was inundated by floodwater

Source: merdeka.com 
Geographically, Banjarmasin is located at an average altitude of $0.16 \mathrm{~m}$ below sea level with the condition of the area being swampy and relatively flat so that almost the entire area will be inundated with water during high tide. Based on these geographical conditions, Banjarmasin means that it is in a position below sea level, so it is not surprising that Banjarmasin is prone to flooding or the terminology of the Banjarese "calap" which has almost the same meaning as flooding. Therefore, Banjarmasin will always face excess water from its capacity, especially at high tide.

The arrangement and layout of rivers must begin from an ecological point of view, and what must be ensured is the number of rivers that naturally exist for centuries and the number of added canals made by the Dutch East Indies Government during the colonial period. These rivers and canals must be maintained because the volume of the tide are remaining the same (in $\mathrm{m} 3$ ) from the past until now, while the capacity of these rivers and canals has been decreased due to the activities of the townspeople. In addition to the facts above, the number of rivers and canals in Banjarmasin also has decreased. Other problems the rivers and canals in Banjarmasin face are:

[1] The loss of some rivers and canals is due to several reasons, but the main cause is due to the construction of buildings both illegal and official, which some of them fully cover the river and some of them cover half of it.

[2] There are still rivers and small canals, but the condition is very concerning because of dirty rivers, polluted by household waste, garbage deposits, industrial waste, clogged garbage or sedimentation, and others. Banjarmasin Environmental Impact Control Agency (Badan Pengendalian Dampak Lingkungan Kota Banjarmasin) which is now renamed Banjarmasin Environment Agency (Dinas Lingkungan) has conducted research that shows that of the ten sample points of river water sampling namely the Basirih River, Mantuil, Pelambuan, Kuin Cerucuk, Kayutangi, Mulawarman, Banua Anyar, Bilu River, Muara Sungai Baru, and Muara Sungai Kelayan, contain (dissolve oxygen) or oxygen content in water only ranges from 4.745.36 milligrams of per liter $(\mathrm{mg} / \mathrm{l})$ from standard $6 \mathrm{mg} / \mathrm{l}$, BOD (biological oxygen demand) or biological oxygen requirement ranges from $2.68-4.05 \mathrm{mg} / \mathrm{l}$, from the standard $2 \mathrm{mg} / \mathrm{l}$. Also, COD (chemical oxygen demand) or chemical oxygen requirement is above standard, 20.5-30.1 mg/1. Meanwhile, a good COD standard is $10 \mathrm{mg} / 1$. Thus, the water of our rivers is already classified as "dangerous" to human health.

[3] These existing rivers can no longer function as water basin areas and as drainage because they are covered in objects that block water from flowing such as buildings or garbage.

The rivers and canals in Banjarmasin need to be reorganized to restore the rivers and canals to be able to function. Various legal policies have been taken by Banjarmasin Government, from issuing regulations on rivers to making policies to establish a River Normalization Task Force. This research is aimed to analyze the Banjarmasin government's regional regulations that regulate the rivers and rivers 
layout, as well as the effectiveness of the legal policy taken by the government as mitigation of the flood problems Banjarmasin faces.

\section{RESEARCH QUESTIONS}

1. How to reformulate the regional regulations of Banjarmasin on rivers so that rivers and canals able to function?

2. What is the effectiveness of the Banjarmasin City Government's policy to organize and layout the rivers as mitigation from flood disasters?

\section{METHOD}

This study uses an interdisciplinary legal research method (socio-legal methodology); where the law (in this case the statutory text) is not only interpreted as an object of value-free study but the law is interpreted as an object that is rich in values (including non-legal values). [iv]

The socio-legal research approach means there are two aspects of the research. First, legal research aspect, which is the object of research in the form of law in the sense of "norm" laws and regulations, focusing a reading and analysis of primary and secondary materials in this case on using various sources of law, then done synthesizing all the issue in context.

Coming to a tentative conclusion. [v]

Second, socio research aspect, i.e. the use of methods and theories of the social sciences about the law to assist researchers in conducting analysis. [vi]In the context of this research, the legal research aspect study is about the existence of local regulations regarding rivers in the city of Banjarmasin seen from the theory and technique of establishing laws and regulations. While the aspect of socio research is seen from the effectiveness of the existence of regional regulations of Banjarmasin City that regulates rivers as mitigation of flood problems that occur in Banjarmasin city.

\section{RESULTS \& DISCUSSION}

\section{a. River Arrangement Through Regulation}

River arrangement problems in Banjarmasin City are unclear from the regulatory side, especially in the Regional Regulations aspect. At least there are some Regional Regulations related to river management that are out of sync and tend to cause conflicting norms. The regulations are:

First, Banjarmasin City Regional Regulation No. 2 of 2007 concerning River Management. This regulation leads to the idea that the river as one of the natural resources that have socio-economic and environmental potential must be developed optimally for the maximum welfare, prosperity of the people and the environment. In addition, the condition of the river in the city of Banjarmasin has suffered a lot of 
siltation and damage so it needs to be managed properly.Management is also necessary because the behavior of the community and the activities and/or businesses of people in the village contribute greatly to the process of siltation and damage to the river in the city of Banjarmasin. In the end, the purpose of this regulation is to restore the condition of the river following its function.Banjarmasin City Regional Regulation is the first regulation directly related to the river, namely Banjarmasin City Regional Regulation No. 2 of 2007 concerning River Management. The consideration of this regulation does not adequately describe whether this regulation is the authority of the Banjarmasin City Government or not since the context of weighing is not based on his juridic, though the juridical foundation is a very important thing in the regulation.

Annex I of Law No. 12 of 2011 on the Establishment of Laws and Regulations mentioned that the point of thought on the consideration of the Law, Provincial Regional Regulation, or District / City Regional Regulation contains philosophical, sociological, and juridical elements that are the considerations and reasons for its formation whose writing is placed sequentially from philosophical, sociological, and juridical.Philosophical elements illustrate that the regulations formed to consider the outlook on life, awareness, and legal ideals that include the atmosphere of physic and philosophy of the Indonesian nation derived from Pancasila and the Opening of the Constitution of the Republic of Indonesia in 1945. Sociological elements describe that regulations are formed to meet the needs of society in various aspects. The juridical element describes that regulations are set up to address legal problems or fill legal gaps by considering existing rules, which will be changed, or that will be repealed to ensure legal certainty and a sense of community justice.

The existence of a very important juridical foundation as stipulated in Annex Law 12 of 2011 is the basis that the elements in this regulation are not fulfilled. Therefore, this regulation can be considered a defect formal since it does not follow the technique of establishing laws and regulations. This regulation consists of XIV CHAPTER, namely General Provisions, River Protection, River Utilization, River Maintenance, River Water Quality Control, Institutional Management, Rights, Obligations and Community Participation, Financing, Supervision, Obligations, Administrative Sanctions, Criminal Provisions, Investigation Provisions, and Closing Provisions.Article 2 of this Regulation is explained the following provisions:

(1) The City Government together with other relevant institutions, each in accordance with its authority and responsibilities, organize efforts to safeguard the river and the surrounding area including:

1. Watershed Management (WATERSHED);

2. Water Damage Control

3. Control of river draining;

4. Protection of river cliffs due to erosion.

(2) In order to protect the functions of the river it is forbidden to change the flow of the river. 
(3) Activities that can damage the function of the river are prohibited such as building buildings on the banks and borders of the river except to provide protection against the river and other benefits that do not damage the river.

(4) It is prohibited to dispose of solid and/or liquid materials and/or waste and/or sewage into or around rivers that are expected or expected to cause pollution or degrade water quality, thus harming and/or harming water users and the environment.

(5) Take something from the river using explosive devices, and/or chemicals, and/or other materials that can damage biota life in the river.

(6) Using transportation facilities that exceed the weight and speed of transportation equipment that has been determined by signs on the river.

If the discernment of the existence of the article is not in accordance with the technique of establishing laws and regulations because the provisions of the prohibition as in paragraph (4) do not have the consequences of sanctions on both administrative and criminal sanctions. Paragraph (5) and paragraph (6) also cause vagueness of the arrangement because the sound is not clear whether the article prohibits or allows.

Second, Banjarmasin City Regional Regulation No. 15 of 2016 on Efforts to Improve River Management. This regulation generally aims to maintain the existence of the river to remain sustainable. The river in the city of Banjarmasin must be managed optimally for the maximum welfare, prosperity of the people, and environmental sustainability. This regulation also wants the involvement of many parties in managing the river.

Third, Banjarmasin City Regional Regulation No. 31 of 2012 concerning the Establishment, Regulation of Utilization of River Borders and Former Rivers. This regulation departs from the idea that the geographical state of the city of Banjarmasin consists of many rivers and is a cultural symbol of the community. The river as one of the sources of water has a function that is very important for the life and livelihood of the community so that it needs to be maintained and continuity of its function by organizing, maintaining, and securing the surrounding area. In addition, this regulation is also based on the consideration that rivers that do not function and or have not been identified need to get handled.The number of overlapping regulations makes the handling of river management can not run optimally. The above regulations are not connected to other regulations and can even be said to be legally flawed when viewed from the aspect of the design of laws and regulations. For example, The No. 15 of 2016 was made unknown based on which regulatory order, because the PP on The River was not used as a legal basis and the previous Regulation No. 2 Of 2007 was not taken into consideration or transitional provisions, so the establishment of a Regulation on Rivers in Banjarmasin City was very confusing and considered legally flawed.

Third, Banjarmasin City Regional Regulation No. 31 of 2012 concerning the Establishment, Regulation of Utilization of River Borders and Former Rivers. Article 16 provides for: 
(1) The former river is controlled by the state.

(2) The department conducts an inventory of the former river and conducts inventory data collection at least once every 5 (five) years.

(3) The former river is prioritized to be restored to function as a river.

(4) The location of the former river can be used to:

1. building water resource infrastructure;

2. cultivation areas and/or protected areas in accordance with the provisions of the legislation.

(5) In the case of the former river as referred to in paragraph (1) recorded as state/regional property, the use of the former river is carried out in accordance with the provisions of the laws and regulations in the field of management of state / regional property.

(6) Everyone who will carry out activities in the former river room as referred to in paragraph (1) shall obtain permission from the Mayor in accordance with his authority.

In connection with The Banjarmasin City Regional Regulation No. 31 of 2012 on The Determination, Regulation of Utilization of River Borders and Former Rivers, indeed for locations on the banks of the river is rarely controlled, because most of the supervision is carried out on main roads. Indeed, sometimes there are reports from the community or there are new buildings that must be controlled and questioned permits.

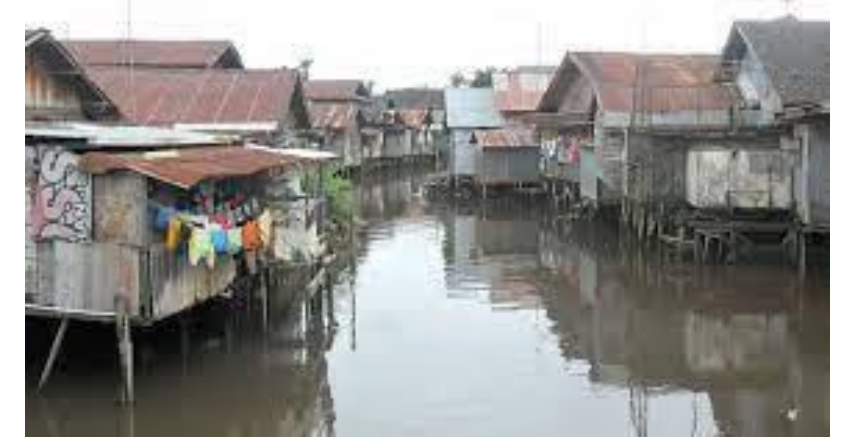

Slums on the river border of Banjarmasin City

Source: kanalkalimantan.com

All the application/implementation of the regulations about the river is the same in the sense of the implementation of supervision and control/patrol, if there is an indication of violation, then the regulation will be applied or carried out reprimand if violated or not, if it violates it will be reprimanded orally, then if not heeded, it will be given a written reprimand (following the Standard Operating Procedure (SOP) of municipal police/Satpol PP).The constraints in the implementation of this regulation are certainly very much, because usually if in the regulation there are criminal sanctions and whether the violations have reached criminal, then the authority to carry out or conduct investigations is civil servant investigators (PNS), but civil servant 
investigators in municipal police (Satpol PP) Banjarmasin city is very limited, so most of us carry out non-judicial regulations. The non-judicial order is only a reprimand of 1 to 3 (following the SOP of Municipal Police/Satpol PP).Carrying out enforcement actions into the realm of minor crimes (tindak pidana ringan) must report to civil servant investigators who have the authority to carry out investigations and continue the process to the Court. For the issue of sanctions that have been given to the community, for these 4 regulations, all these regulations have never been at all to the stage of enforcement of minor crimes (tipiring), but if the type of verbal and written reprimand has been implemented for those who commit violations as stipulated in the 4 regulations.

Satpol PP Kota Banjarmasin as much as possible to carry it out, be it the regulation, supervision, and enforcement of the material substance of the regulation, because the function of municipal police/Satpol PP is the enforcement of laws and regulations.The garbage buried in the rivers is result that causes the river in Banjarmasin City to become polluted, so it becomes the obligation of the Government to restore the state of the river, in the context of the Banjarmasin City municipal police/Satpol PP, the main tasks/tupoksi is to process those who commit violations, one of which is by making policies on garbage that closes the river flow, other agencies are more instrumental.In addition to the above regulations, the regulation that has only been issued in the past few years is the Banjarmasin City Regional Regulation No. 15 of 2016 on Efforts to Improve River Management. This regulation consists of VII chapters, namely: General Provisions, Purposes and Objectives, River Management, River Information Systems, Community Empowerment, Financing, and Closing Provisions.In article 6 of this Regulation stipulates that the management of the river carried out must pay attention to several things, including:

1. Flood and inundation control as a result of local rains, river discharge from upstream and tidal fluctuations of rivers;

2. Controlled quantity and feasibility of river water quality as one of the raw water sources of Banjarmasin City;

3. Support the establishment of local and regional river transportation systems;

4. Not eliminating the historical and cultural identity of the river, in order to strengthen the Tourism of the River Banjarmasin City.

5. Environmentally minded, with no detracting from the principles of safety and aesthetics.

This regulation regulates several functions of rivers such as rivers as flood control systems and puddles. In this function, local governments are required to draw up an integrated river management development plan to control the potential for flooding and inundation, and strive to maintain cultural assets and have been established following applicable regulations using flood risk mapping and water management (flood risk and water management). The second is the river as one of the raw water sources, the third river is the river transportation infrastructure, and the 
fourth is the river as a cultural and tourism identity. The three above are seen arranging the same object that is about the river. If we look, the rules are very related. Therefore, some of the above regulations need to be researched related to the material content. If possible this regulation can be simplified into one regional regulation only since many regulations have the potential to inhibit its application.

From the point of legal arrangement of river arrangements in Banjarmasin, it turns out that the Banjarmasin City Government does not have good legal documentation. The Banjarmasin City Government-issued Regulation No. 15 of 2016 on Efforts to Improve River Management, not related to the previous Regulation and can even be said to be an illegitimate child because of Regulation No. 15, 2016, there was no mention of regulated delegation which, as not mentioning Government Regulation No. 38 of 2011 on the River as a legal basis and even the scope of this regulation is unclear. If discussed more in many ways found irregularities in Regulation No. 15, 2016. This messed arrangement has implications for the legal basis of actions carried out by the Banjarmasin City Government because two applicable regulations regulate the same object but different orientations.

Seeing the condition of regulations like this, it is necessary to simplification of local regulations, according to Petrus Kadek Suherman this simplification aims to:

1. Simplification to improve the understanding of community law, because the less number of regulations at the local government level will be able to further improve the understanding of community law because the community as users of the regulation will be able to understand the rules as a whole.

2. Simplification to avoid and minimize the occurrence of conflicting legal contradictions or rules. The number of existing regulations and made by local governments that are not following the needs will lead to a higher potential for legal contradictions.

This regulatory function is important in river structuring as stated by Geoffrey E. Petts who stated river regulation is the act of controlling river water level or the variability of river flows to meet human demands for domestic and industrial water supplies, for irrigation agriculture, for hydroelectric power generation, for navigation, and flood control and land drainage. [vii] Explicitly stated by some scholars that today, river regulation remains an important tool for socio-economic development but local controls have been replaced by the coordinated regulation of flows throughout entire river basins and large-scale water transfers from wet to dry regions. [viii]

\section{b. $\quad$ Structuring River Through Institutional}

The importance of structuring rivers through institutions can be seen in an old paper from Irving K. Fox entitled Institutions for Water Management in a Changing World, Natural Resources Journal, Volume 16 Issue 4 Symposium on Water Resources Management in a Changing World Fall 1976. [ix] Even now with the complex problem of this river, especially water problems, it is necessary for institutions that integrated as 
written by Mathew Kurian, about Institutions for integrated water resources management in river basins: A synthesis of IWNI Research, February 2004[x]

\subsection{Management Agency Independence}

In 2007 when the process of establishing the Banjarmasin City Regulation No. 2 , 2007, on the river. At that time came the idea that the river was managed by a separate independent Institution, meaning that it was not taken care of by the Head of Field of the Public Works and Public Housing Office. From this thought, a special institution was formed, namely the Water Resources and Drainage Office, for approximately 10 years the Service was operational, then in 2016 then by the Central Government, the Service was liquidated because there was no nomenclature in the laws and regulations so that the Water Resources and Drainage Office was removed and river affairs were returned to the Public Works and Public Housing (PUPR) Office. During the Water Resources and Drainage Office is operating, there are visible tangible results from the work of the Agency including the arrangement of existing rivers by conducting the River Normalization Program and after the Water Resources and Drainage Office removed the river normalization program to be stopped.

Originally the name of the Agency in 2009 was Office of River Management and Drainage, but in 2011 it changed to the Water Resources and Drainage Service (this name change is following the Central Government). However, in 2016 the office was gone. The information obtained, the loss of the service because it adjusts to the Central Government and is finally becoming one into the Public Works and Public Housing (PUPR) Office because the authority of Water Resources is under the Director-General of PUPR. Actually, according to the Head of River Affairs of the Public Works and Public Housing Office of Banjarmasin City, Banjarmasin City should have its own River Service, because the geography of the river in the city of Banjarmasin has its peculiarities compared to the rivers in other areas that can be counted by finger, while the rivers in the city of Banjarmasin are very numerous, there should be lex specialis related to the existence of the River Service itself.

[xi]If we make a comparison, an affair that is carried out by a Regional Service Institution compared to an affair that is carried out by a specialist institution is different in terms of human resources and from the budget prepared. The affair would be easier when it was carried out by a specialist institution since it can deal directly with Central Government, but when it is carried out by a Regional Service Institution, the affairs is rather difficult since it must follow some tight procedures. The budget is also very much different when in Regional Service Institution, the budget is cut to half from down to half of the initial budget when it was still a separate service. At the time it was still a separate service, the Natural Resources and Drainage Office in a year could get a river management budget of 60-70 billion rupiahs, but after the merging to the Public Works and Public Housing (PUPR) Office Service, the budget is cut down to 20 billion rupiahs, and the movement was not as free as it used to be. The task or scope after the merging of the service becomes smaller, even though it is still the same task and scope 
when it is still a separate service. However, since the merging, the budget and human resources are reduced, the implementation of the task and its scope becomes very difficult to apply thoroughly.

\subsection{Asset Documentation}

With the geographical condition of Banjarmasin as mentioned above, then mathematically how big the volume of activities of the city residents such as building buildings and infrastructure facilities, then the city environment is lacking/losing water capacity, so it is natural that during the Dutch East Indies made additional canals in exchange for the lack of water capacity due to construction activities carried out by the people of Banjarmasin residents who continue to increase while the rivers that existed at that time were unable to accommodate the discharge of water. In 2011 based on the Decree of the Mayor of Banjarmasin No. 158 of 2011 on the Determination of Rivers as Public Facilities and Assets of the City Government, there were 102 rivers in Banjarmasin. The data is as follows:[xii]

DAFTAR LAMPIRAN NAMA-NAMA SUNGAI

\begin{tabular}{|c|c|c|c|c|c|c|c|}
\hline No & Nama Sungal & Kelas Sungal & Panjang $(m)$ & Lebar max. (m) & Lebar min. $(m)$ & Luas (m2) & Dalam max. (m) \\
\hline 1 & Barito & Besar & $11.500,00$ & 725 (lebar kesehehruhan) & & & 14 \\
\hline 2 & Alalak & Besar & $13.705,00$ & 188 & 25 & $1.246 .582,50$ & 12 \\
\hline 3 & Martapura & Besar & $25.066,00$ & 212 & 40 & $3.145 .783,00$ & 12 \\
\hline 4 & Belasung & Kecti & 95,00 & 7 & 2 & 427,50 & 1 \\
\hline 5 & Gg Melati & Kecill & 117,00 & 4 & 1 & 292,50 & 1 \\
\hline 6 & Telawang & Kecll & 128,00 & 1 & 0 & 64,00 & 1 \\
\hline 7 & Pasar Kamboja & Kecil & 157,00 & 5 & 1 & 471,00 & 0 \\
\hline 8 & Tapis Kandal & Kecll & 169,00 & 0 & 0 & - & 1 \\
\hline 9 & Manggis & Kecll & 185,00 & 62 & 2 & $5.920,00$ & 0 \\
\hline 10 & Parit & Kecll & 201,00 & 4 & 1 & 502,50 & 0 \\
\hline 11 & Saka Bangun & Kecil & 207,00 & 4 & 2 & 621,00 & 2 \\
\hline 12 & Anak Pangeran ki 2 & Kecil & 232,00 & 6 & 1 & 812,00 & 1 \\
\hline 13 & Bahaur & Kecil & 233,00 & 0 & 0 & $\div$ & 1 \\
\hline 14 & Surgl Mufti & Kecill & 246,00 & 16 & 2 & $2.214,00$ & 1 \\
\hline 15 & Banylur Utara & Kecll & 247,00 & 0 & 0 & - & 1 \\
\hline 16 & Gatot & Kecll & 251,00 & 2 & 0 & 251,00 & 1 \\
\hline 17 & Anak Kldaung & Kecil & 260,00 & 8 & 2 & $1.300,00$ & 1 \\
\hline 18 & Panggal & Kecil & 265,00 & 11 & 2 & $1.722,50$ & 0 \\
\hline 19 & Sidomulyo & Kecil & 269,00 & 6 & 0 & 807,00 & 1 \\
\hline 20 & Skip lama & Kecil & 335,00 & 5 & 1 & $1.005,00$ & 1 \\
\hline 21 & Sakaban Pasai & Kecil & 339,00 & 0 & 0 & - & 1 \\
\hline 22 & Sifa & Kecil & 340,00 & 10 & 1 & $1.870,00$ & 1 \\
\hline 23 & Benawa & Kecil & 382,00 & 4 & 1 & 955,00 & 1 \\
\hline 24 & Lumbah & Kecil & 396,00 & 7 & 1 & $1.584,00$ & 0 \\
\hline 25 & Jeruju & Kecli & 402,00 & 4 & 1 & $1.005,00$ & 1 \\
\hline 26 & Laksona Intan & Kecil & 467,00 & 15 & 1 & $3.736,00$ & 0 \\
\hline 27 & G8 Saadah & Kecil & 473,00 & 3 & 1 & 946,00 & 1 \\
\hline 28 & Simpang Tangga & Kecil & 487,00 & 9 & 1 & $2.435,00$ & 1 \\
\hline 29 & Anak Pelambuan Kiri & Kecil & 498,00 & 16 & 3 & $4.731,00$ & 2 \\
\hline 30 & Meratus & Kecil & 501,00 & 3 & 1 & $1.002,00$ & 0 \\
\hline 31 & Billu & Kecil & 530,00 & 6 & 0 & $1.590,00$ & 1 \\
\hline 32 & Antasan Raden & Kecil & 567,00 & 8 & 1 & $2.551,50$ & 1 \\
\hline 33 & Anak Miai & Kecil & 572,00 & 7 & 2 & $2.574,00$ & 1 \\
\hline 34 & Pandal & Kech & 591,00 & 5 & 1 & $1.773,00$ & 0 \\
\hline 35 & Anak Pelambuan Kanan & Kecil & 622,00 & 12 & 3 & $4.665,00$ & 2 \\
\hline 36 & Cendrawasih & Kecil & 636,00 & 5 & 1 & $1.908,00$ & 1 \\
\hline 37 & II Balli & Kecil & 644,00 & 3 & 1 & $1.288,00$ & 1 \\
\hline 38 & Airmantan & Kecil & 662,00 & 23 & 9 & $10.592,00$ & 1 \\
\hline 39 & Kerukan & Kecil & 682,00 & 23 & 1 & $8.184,00$ & 1 \\
\hline 40 & Gardu & Kecil & 709,00 & 14 & 2 & $5.672,00$ & 1 \\
\hline 41 & Antasan eondan & Kecil & 715,00 & 37 & 5 & $15.015,00$ & 2 \\
\hline 42 & Tatas & Kecil & 736,00 & 11 & 3 & $5.152,00$ & 1 \\
\hline 43 & Hallinau & Kecil & 767,00 & 16 & 3 & $7.286,50$ & 2 \\
\hline 44 & Gudang & KeClI & 772,00 & 10 & 1 & 4.246 .00 & 1 \\
\hline 45 & Keramat & Kecil & 793,00 & 7 & 0 & $2.775,50$ & 1 \\
\hline 46 & Kuripan & Kecil & 822,00 & 7 & 0 & $2.877,00$ & 1 \\
\hline 47 & Pasar Rambal & Kecil & 889,00 & 5 & 1 & $2.667,00$ & 0 \\
\hline 48 & Sugalling & Kecll & 931,00 & 7 & 1 & $3.724,00$ & 1 \\
\hline 49 & Tallan & Kecil & 961,00 & 16 & 0 & $7.688,00$ & 0 \\
\hline 50 & Mial & Kech & $1.002,00$ & 6 & 1 & $3.507,00$ & 0 \\
\hline 51 & Pengambangan & Kecill & $1.165,00$ & 22 & 1 & $13.397,50$ & 1 \\
\hline 52 & Buaya & Kecil & $1.263,00$ & 12 & 1 & $8.209,50$ & 1 \\
\hline 53 & Anak Banyiur & Kecil & $1.298,00$ & 17 & 2 & $12.331,00$ & 1 \\
\hline 54 & Jagad Baya & Kecil & $1.310,00$ & 0 & 0 & - & 1 \\
\hline 55 & Kidaung & Kecil & $1.364,00$ & 14 & 2 & $10.912,00$ & 1 \\
\hline 56 & Pacinan & Kedil & $1.453,00$ & 5 & 0 & $3.632,50$ & 0 \\
\hline 57 & Banylur & Kecil & $1.554,00$ & 32 & 2 & $26.418,00$ & 3 \\
\hline
\end{tabular}




\begin{tabular}{|c|c|c|c|c|c|c|c|}
\hline 58 & Jingah & Kecil & $1.578,00$ & 14 & 2 & $12.624,00$ & 1 \\
\hline 59 & Gayam & Kecil & $1.915,00$ & 20 & 1 & $20.107,50$ & 1 \\
\hline 60 & Tungku & Kecil & $2.028,00$ & 22 & 1 & $23.322,00$ & 1 \\
\hline 61 & Saka Permal & Kecil & $2.290,00$ & 37 & 1 & $43.510,00$ & 1 \\
\hline 62 & Anak Pangeran $\mathrm{kl} 1$ & Kecil & $2.450,00$ & 25 & 1 & $31.850,00$ & 1 \\
\hline 63 & Kuin & Kecll & $3.909,00$ & 61 & 7 & $132.906,00$ & 4 \\
\hline 64 & Duyung & Saluran & $1.001,00$ & 21 & 3 & $12.012,00$ & 1 \\
\hline 65 & Beflitung Darat & Saluran & $1.304,00$ & 5 & 2 & $4.564,00$ & 1 \\
\hline 66 & Batas Belitung Darat & Saluran & $1.369,00$ & 8 & 1 & $6.160,50$ & 1 \\
\hline 67 & Anjir mulawarman & Saluran & $1.778,00$ & 31 & 11 & $37.338,00$ & 2 \\
\hline 68 & Ahmad Yani & Saluran & $3.285,00$ & 13 & 0 & $21.352,50$ & 1 \\
\hline 69 & Saka Mangkuk Kiri Kiri & Sedang & 496,00 & 26 & 4 & $7,440,00$ & 1 \\
\hline 70 & Handil Bujur KIri & Sedang & 534,00 & 11 & 5 & $4.272,00$ & 1 \\
\hline 71 & Saka Mangkuk Kiri & Sedang & 681,00 & 8 & 2 & $3,405,00$ & 1 \\
\hline 72 & Simpang Jelal Kiri & Sedang & 768,00 & 11 & 3 & $5.376,00$ & 1 \\
\hline 73 & Bagau Kanan Kanan & Sedang & 985,00 & 10 & 2 & $5.910,00$ & 1 \\
\hline 74 & Handil Bamban & Sedang & $1.008,00$ & 15 & 2 & $8.568,00$ & 1 \\
\hline 75 & Bagau KIrI & Sedang & $1.055,00$ & 34 & 11 & $23.737,50$ & 1 \\
\hline 76 & Antasan Segera & Sedang & $1.295,00$ & 38 & 4 & $27.195,00$ & 1 \\
\hline 77 & Peradaban & Sedang & $1.387,00$ & 7 & 1 & $5.548,00$ & 1 \\
\hline 78 & Handil Jatuh & Sedang & $1.489,00$ & 5 & 0 & $3.722,50$ & 1 \\
\hline 79 & Pelambuan & Sedang & $1.509,00$ & 43 & 4 & $35.461,50$ & 3 \\
\hline 80 & Pekapuran & Sedang & $1.534,00$ & 21 & 0 & $16.107,00$ & 1 \\
\hline 81 & Darapan & Sedang & $1.593,00$ & 15 & 1 & $12.744,00$ & 1 \\
\hline 82 & Awang & Sedang & $1.999,00$ & 62 & 17 & $78.960,50$ & 3 \\
\hline 83 & Pangeran & Sedan 8 & $2.009,00$ & 34 & 1 & $35.157,50$ & 0 \\
\hline 84 & Veteran & Sedans & $2.087,00$ & 10 & 1 & $11.478,50$ & 1 \\
\hline 85 & Gampa & Sedang & $2.186,00$ & 24 & 5 & $31.697,00$ & 1 \\
\hline 86 & Simpang Jelai & Sedang & $2.250,00$ & 38 & 5 & $48.375,00$ & 3 \\
\hline 87 & Handlli Bujur & Sedang & $2.341,00$ & 44 & 0 & $51.502,00$ & 1 \\
\hline 88 & Andal & Sedang & $2.624,00$ & 25 & 4 & $38.048,00$ & 6 \\
\hline 89 & Tatah Bangkal & Sedang & $2.855,00$ & 37 & 8 & $64.237,50$ & 1 \\
\hline 90 & Runggun & Sedang & $3.029,00$ & 23 & 0 & $34.833,50$ & 3 \\
\hline 91 & Kelayan Kecll & Sedang & $3.057,00$ & 43 & 3 & $70.311,00$ & 2 \\
\hline 92 & Guring & Sedang & $3.105,00$ & 19 & 0 & $29.497,50$ & 1 \\
\hline 93 & Kelayan & Sedang & $3.227,00$ & 26 & 11 & $59.699,50$ & 2 \\
\hline 94 & Perigi & Sedang & $3.294,00$ & 20 & 1 & $34.587,00$ & 2 \\
\hline 95 & Saka Harang & SedanB & $3.337,00$ & 27 & 1 & $46.718,00$ & 4 \\
\hline 96 & Teluk Dalam & Sedang & $3.428,00$ & 63 & 0 & $107.982,00$ & 2 \\
\hline 97 & Pemurus & Sedang & $3.569,00$ & 31 & 4 & $62.457,50$ & 1 \\
\hline 98 & Tatah Belayung & Sedang & $4.143,00$ & 31 & 0 & $64.216,50$ & 2 \\
\hline 99 & Kuin Kecil & Sedang & $4.298,00$ & 61 & 0 & $131.089,00$ & 2 \\
\hline 100 & Basirih & Sedang & $4.390,00$ & 62 & 7 & $151.455,00$ & 10 \\
\hline 101 & Saka Mangkuk & Sedang & $4.914,00$ & 18 & 0 & $44.226,00$ & 1 \\
\hline 102 & Bagau & Sedang & $5.757,00$ & 57 & 1 & $166.953,00$ & 4 \\
\hline & TOTAL & & $\begin{array}{r}173.803,00(\mathrm{~m}) \\
173,80(\mathrm{~km})\end{array}$ & & & $\begin{array}{r}6.466 .390,00(\mathrm{mz}) \\
646,64(\mathrm{Ha}) \\
6,47(\mathrm{km2}) \\
\end{array}$ & \\
\hline
\end{tabular}

\section{CATATAN :}

1. Total panjang dan luas tidak termasuk sungal Barito

2. Sumber data :

a. Oatabase sungai Kota Banjarmasin tahun 2009 survey tim P4W IPB,
b. Katalog sungai.

Then the data was updated again in 2020 with The Mayor of Banjarmasin Decree No. 647 of 2020 on the Determination of Rivers as Public Facilities and Assets of the Banjarmasin City Government. The data is as follows: ${ }^{\mathrm{i}}$ 
LAMPIRAN

KEPUTUSAN WALIKOTA BANJARMASIN

NOMOR : $\%$ Tahun 2020

TENTANC

PENETAPAN SUNGAI SEBAGAI FASILITAS UMUM ASET PEMERINTAH KOTA BANJARMASIN

\begin{tabular}{|c|c|c|c|c|c|}
\hline Kecamatan & NO & Nama Sungai & $\begin{array}{l}\text { Panjang Sungai } \\
(m)\end{array}$ & $\begin{array}{l}\text { Lebar Sungai } \\
\text { (m) }\end{array}$ & $\begin{array}{l}\text { Kedalaman Sungai } \\
\text { (m) }\end{array}$ \\
\hline \multirow{67}{*}{$\begin{array}{c}\text { Kecamatan Banjarmasin Utara } \\
70 \\
\text { sungai }\end{array}$} & 1 & \multirow{2}{*}{\begin{tabular}{|l|} 
Antasan \\
Jagad Baya
\end{tabular}} & 584,930 & 13 & $1-2$ \\
\hline & 2 & & 1172,315 & 28 & $1-1,5$ \\
\hline & 3 & Anak Pangeran Ki 1 & 909,431 & 13 & $1-1,5$ \\
\hline & 4 & Tapis Kandal & 527,804 & 22 & $1-1,5$ \\
\hline & 5 & Lutung & 471,617 & 15 & $1-1,5$ \\
\hline & 6 & Panggang & 194,806 & 12 & $1-1,5$ \\
\hline & 7 & Banyiur Utara & 533,593 & 25 & $1-1,5$ \\
\hline & 8 & Jeruju Besar & 425,709 & 22 & $1-1,5$ \\
\hline & 9 & Pandai & 782,740 & 30 & $1-1,5$ \\
\hline & 10 & Anak Tungku Kal & 227,252 & 19 & $1-1,5$ \\
\hline & 11 & Tungku & 2025,016 & 30 & $1-1,5$ \\
\hline & 12 & Ruyung & 593,564 & 16 & $1-1.5$ \\
\hline & 13 & Anak Kidaung Ki 1 & 239.448 & 6 & $1-1.5$ \\
\hline & 14 & Anak Simpang Jarak Ka 1 & 285,237 & 18 & 1.1 .5 \\
\hline & 15 & Anak Pangeran Ka 2 & 680,099 & 11 & $1-2$ \\
\hline & 16 & Anak Pangeran Ka 1 & 121,744 & 8 & 1.2 \\
\hline & 17 & Jarak & 437,806 & 18 & $1-2$ \\
\hline & 18 & Anak Simpang Jarak Ka 2 & 217,661 & 15 & $1-2$ \\
\hline & 19 & $\begin{array}{l}\text { Simpang Jarak } \\
\text { Sigaling }\end{array}$ & 1670,616 & 30 & $1-2$ \\
\hline & $\begin{array}{l}20 \\
21\end{array}$ & $\begin{array}{l}\text { Sigaling } \\
\text { Pangeran }\end{array}$ & 1087,204 & 30 & $1-2$ \\
\hline & $\begin{array}{l}21 \\
22\end{array}$ & \begin{tabular}{|l} 
Pangeran \\
Simpang Tangga
\end{tabular} & 1775,510 & 65 & $0.5-1$ \\
\hline & $\begin{array}{l}22 \\
23\end{array}$ & $\begin{array}{l}\text { Simpang Tangga } \\
\text { Anak Pangeran Ki } 2\end{array}$ & 723,371 & 30 & $0.5-1$ \\
\hline & $\begin{array}{l}23 \\
24\end{array}$ & $\begin{array}{l}\text { Anak Pangeran Ki } 2 \\
\text { Awang }\end{array}$ & 504,648 & 8 & 1.2 \\
\hline & 25 & $\begin{array}{l}\text { Awang } \\
\text { Alalak }\end{array}$ & 1942,953 & 90 & $2-4$ \\
\hline & 26 & Andaia & 10707,939 & 100 & 2.4 \\
\hline & 27 & Gg Paba & $\begin{array}{r}2557,466 \\
487,214\end{array}$ & 40 & $\frac{2-4}{0.5-1}$ \\
\hline & 28 & Kuin & $\begin{array}{r}487,214 \\
3883,641\end{array}$ & $\begin{array}{l}10 \\
90\end{array}$ & $\begin{array}{l}0.5-1 \\
0.5-1\end{array}$ \\
\hline & 29 & Anak Jagad Baya Ki 1 & $\begin{array}{r}3883,641 \\
149,651\end{array}$ & $\begin{array}{c}90 \\
8\end{array}$ & $\begin{array}{l}0.5-1 \\
1-1.5\end{array}$ \\
\hline & 30 & Pelambuan & 441,469 & 20 & $2-4$ \\
\hline & 31 & Gg Kurnia & 205,599 & 15 & $0.5-1$ \\
\hline & 32 & Simpang Kidaung & 158,120 & 15 & $0.5-1$ \\
\hline & 33 & Sintik & 297,688 & 12 & $0.5-1.5$ \\
\hline & $\begin{array}{l}34 \\
35\end{array}$ & Tabukan & 252,093 & 25 & $0.5 \cdot 1$ \\
\hline & $\begin{array}{l}35 \\
36\end{array}$ & Samping Mesjid & 176,521 & 6 & $0.5-1$ \\
\hline & $\begin{array}{l}36 \\
37\end{array}$ & Al Falah & 143,130 & 10 & $0.5-1$ \\
\hline & $\begin{array}{l}37 \\
38\end{array}$ & Halayung & 693,119 & 20 & $0.5-1$ \\
\hline & $\begin{array}{l}38 \\
39\end{array}$ & $\begin{array}{l}\text { Anak Picis Kandal } \\
\text { Ulak }\end{array}$ & 164,865 & 10 & $\begin{array}{l}0.5-1 \\
0.5-1\end{array}$ \\
\hline & 40 & $\begin{array}{l}\text { Ulak } \\
\text { Daud }\end{array}$ & $\begin{array}{l}186,014 \\
105,604\end{array}$ & 10 & $\begin{array}{l}0.5-1 \\
0.5-1\end{array}$ \\
\hline & 41 & Saka Dingin & $\begin{array}{l}105,604 \\
331,480\end{array}$ & $\begin{array}{l}19 \\
22\end{array}$ & \\
\hline & 42 & Sudirapi & 215,244 & $\begin{array}{l}22 \\
18\end{array}$ & $\begin{array}{l}0.5-1 \\
0.5-1\end{array}$ \\
\hline & 43 & Anak Tungku Ka 2 & 383,611 & $\begin{array}{l}18 \\
18\end{array}$ & $\begin{array}{l}0.5-1 \\
0.5-1\end{array}$ \\
\hline & 44 & Anak Tungku Ka 3 & 373,967 & 9 & $\begin{array}{l}0.5-1 \\
0.5-1\end{array}$ \\
\hline & 45 & Anak Surgi Mufti & 122,845 & 7 & $\begin{array}{l}0.5-1 \\
0.5-1\end{array}$ \\
\hline & 46 & Gg Kemuning & 209,212 & 5 & $\begin{array}{l}0.5-1 \\
0.5-1\end{array}$ \\
\hline & 47 & Gg Gawi Sabumi & 98,484 & 6 & $\begin{array}{c}0.5-1 \\
0.5-1.5\end{array}$ \\
\hline & 48 & Jeruju Kecil & 989,402 & 12 & $\begin{array}{l}0.5-1.5 \\
0.5-1.5\end{array}$ \\
\hline & 49 & Sungai Mesjid Alyakin & 495,146 & 20 & $\begin{array}{l}0.5-1.5 \\
0.5-1.5\end{array}$ \\
\hline & 50 & Anak Sungai Simp.Tangga & 214,264 & 10 & $\begin{array}{l}0.5-1.5 \\
0.5-1.5\end{array}$ \\
\hline & 51 & Attanwir & 700,031 & 10 & $\begin{array}{l}0.5-1.5 \\
0.5-1.5\end{array}$ \\
\hline & 52 & Jingah & 2302,925 & 25 & $\begin{array}{l}0.5-1.5 \\
0.5-1.5\end{array}$ \\
\hline & 53 & Mujib & 126,015 & 14 & $\begin{array}{l}0.5-1.5 \\
0.5-1.5\end{array}$ \\
\hline & 54 & Pematang & 354.909 & 6 & $\begin{array}{l}0.5-1.5 \\
0.5-1.5\end{array}$ \\
\hline & 55 & Surgi Mufti & 398,324 & 20 & $\begin{array}{l}0.5-1.5 \\
0.5-1.5\end{array}$ \\
\hline & 56 & Juragan Kusin & 109,235 & 11 & $\begin{array}{l}0.5-1.5 \\
0.5 \cdot 1.5\end{array}$ \\
\hline & 57 & Gayam & 282,907 & 18 & $\begin{array}{c}0.5-1.5 \\
0.5-2\end{array}$ \\
\hline & $\begin{array}{l}58 \\
59\end{array}$ & $\begin{array}{l}\text { Miai } \\
\text { Anak Kidaung Ki } 2\end{array}$ & 2745,254 & 45 & $\begin{array}{l}0.5-2 \\
0.5-2\end{array}$ \\
\hline & $\begin{array}{l}59 \\
60\end{array}$ & $\begin{array}{l}\text { Anak Kidaung Ki } 2 \\
\text { Kidaung }\end{array}$ & 343,233 & 6 & $\begin{array}{c}0.5-2 \\
0.5-1.5\end{array}$ \\
\hline & 61 & \begin{tabular}{|l} 
Kidaung \\
Picis Kandal
\end{tabular} & 1662,267 & 55 & $\begin{array}{l}0.5-1.5 \\
0.5-1.5\end{array}$ \\
\hline & 62 & \begin{tabular}{|l} 
Picis Kandal \\
Anak Sakaban Pasai
\end{tabular} & 463.282 & 18 & $\begin{array}{l}0.5-1.5 \\
0.5-1.5\end{array}$ \\
\hline & 63 & $\begin{array}{l}\text { Anak Sakaban Pasai } \\
\text { Sakaban Pasai }\end{array}$ & 104,535 & 12 & $\begin{array}{l}0.5-1.5 \\
0.5-1.5\end{array}$ \\
\hline & 64 & Pirawas & \begin{tabular}{|l|}
439.191 \\
194.238
\end{tabular} & 22 & $\begin{array}{l}0.5-1.5 \\
0.5-1.5\end{array}$ \\
\hline & 65 & Bandi & $\begin{array}{l}194,238 \\
207,450\end{array}$ & 12 & $\begin{array}{l}0.5-1.5 \\
0.5-1.5\end{array}$ \\
\hline & 66 & Piduku & $\begin{array}{r}207,450 \\
85,471\end{array}$ & 4 & $\begin{array}{l}0.5-1.5 \\
0.5-1.5\end{array}$ \\
\hline & 67 & Bandarungan Kecil & $\begin{array}{l}85,471 \\
77,368\end{array}$ & 6 & $\begin{array}{l}0.5-1.5 \\
0.5-1.5\end{array}$ \\
\hline & 68 & Anak Jagad Baya Ka 1 & $\begin{array}{r}77,368 \\
212,182\end{array}$ & 12 & $\begin{array}{l}0.5-1.5 \\
0.5-1.5\end{array}$ \\
\hline & 69 & Anak Pangeran Ki Kanan & $\begin{array}{l}212,182 \\
618,004\end{array}$ & 6 & $\begin{array}{l}0.5-1.5 \\
0.5-1.5\end{array}$ \\
\hline & 70 & Saka Pelangi & $\begin{array}{l}618,004 \\
872.534\end{array}$ & 12 & $\begin{array}{l}0.5-1.5 \\
0.5-1.5\end{array}$ \\
\hline & & & 872.534 & 25 & $\begin{array}{l}0.5-1.5 \\
0.5-1.5\end{array}$ \\
\hline Kecamatan Banjarmasin Timur & 1 & Anak Gampa Ka 2 & & & \\
\hline $\begin{array}{c}\text { Kecamatan Banjarmasin Timur } \\
50\end{array}$ & 2 & Anak Darapan & $\begin{array}{r}932,327 \\
1034,729\end{array}$ & & \\
\hline sungai & 3 & Pangambangan & $\begin{array}{r}932,327 \\
1034,729 \\
1156,575\end{array}$ & $\begin{array}{l}12 \\
12\end{array}$ & $0.5-1.5$ \\
\hline & 4 & Keramat & $\begin{array}{r}1156,575 \\
846,353\end{array}$ & 34 & $0.5 \cdot 1.5$ \\
\hline & 5 & Gardu & $\begin{array}{r}846,353 \\
2270,277\end{array}$ & 50 & $0.5-1.5$ \\
\hline & 6 & Anak Sungai Veteran & $\begin{array}{r}2270,277 \\
401,185\end{array}$ & 40 & $0.5-1.5$ \\
\hline & 7 & Lumbah & $\begin{array}{l}401,185 \\
391,066\end{array}$ & 10 & $1-2$ \\
\hline & 8 & Bilu & & & \\
\hline & 9 & Manggis & & & \\
\hline & & & 2064,875 & 20 & $\begin{array}{c}0.5-1.5 \\
1.2\end{array}$ \\
\hline
\end{tabular}




\begin{tabular}{|c|c|c|c|c|c|}
\hline Kecamatan & NO & Nama Sungai & $\begin{array}{l}\text { Panjang Sungai } \\
\text { (m) }\end{array}$ & $\begin{array}{c}\text { Lebar Sungai } \\
\text { (m) }\end{array}$ & $\begin{array}{c}\text { Kedalaman Sungai } \\
\text { (m) }\end{array}$ \\
\hline & 11 & Siaga & 715,413 & 22 & $0,50-1,5$ \\
\hline & 12 & Guring & 3072,525 & 70 & $0,50-1,5$ \\
\hline & 13 & Kuripan & 817,257 & 17 & $0,50-1,5$ \\
\hline & 14 & Simpang Layang & 1454,581 & 30 & $1-2$ \\
\hline & 15 & Simpang Limau & 2687,527 & 30 & $1-2$ \\
\hline & 16 & Handil Jatuh & 2965,712 & 15 & $1-2$ \\
\hline & 17 & Simpang Bamban & 1266,784 & 18 & $1-2$ \\
\hline & 18 & Simpang Berahman & 1146,711 & 16 & $1-2$ \\
\hline & 19 & Bajang & 616.704 & 20 & $0,50-1,5$ \\
\hline & 20 & Antasan Segera & 782,842 & 32 & $0,50-1,5$ \\
\hline & 21 & Lulut & 4942,769 & 45 & $1-2$ \\
\hline & 22 & Tatah & 1028,410 & 28 & $0,50-1,5$ \\
\hline & 23 & Anak Gampa Ka 1 & 618,827 & 8 & $0,50-1,5$ \\
\hline & 24 & Banua Hanyar 1 & 560,511 & 20 & $0,50-1,5$ \\
\hline & 25 & Jengankit & 960,875 & 28 & $1-2$ \\
\hline & $\begin{array}{l}26 \\
27\end{array}$ & Darapan & 2600,849 & 35 & $1-2$ \\
\hline & $\begin{array}{l}27 \\
28\end{array}$ & & 2961,495 & 60 & \\
\hline & 29 & $\begin{array}{l}\text { Banua Hanyar } 2 \\
\text { Katak }\end{array}$ & $\begin{array}{l}324,656 \\
383,323\end{array}$ & $\begin{array}{l}12 \\
14\end{array}$ & $\begin{array}{l}1-2 \\
1-2\end{array}$ \\
\hline & 30 & Simpang Rimis & 577,050 & 18 & $1-2$ \\
\hline & 31 & Anak Pangambangan $\mathrm{Ki} 1$ & 316,753 & 7 & $0.5-1$ \\
\hline & 32 & Anak Pangambangan Ka 1 & 95,200 & 10 & $0.5-1$ \\
\hline & 33 & Anak Pangambangan Ka 2 & 147,452 & 7 & $0.5-1$ \\
\hline & 34 & Anak Pangambangan Ka 3 & 117,108 & 7 & $0.5-1$ \\
\hline & 35 & Anak Pangambangan Ki 3 & 130,887 & 6 & $0.5-1$ \\
\hline & 36 & Anak Pangambangan Ki 2 & 121,225 & 10 & $0.5-1$ \\
\hline & 37 & Anak Keramat Ki 1 & 138,744 & 8 & $0.5-1$ \\
\hline & 38 & Anak Keramat Ka 1 & 102,247 & 5 & $0.5-1$ \\
\hline & 39 & Teluk Mendung & 165,168 & 30 & $0.5-1$ \\
\hline & 40 & Anak Simpang Nangka & 2279,500 & 17 & $0.5-1$ \\
\hline & $\begin{array}{l}41 \\
42\end{array}$ & $\begin{array}{l}\text { Kuburan Arab } \\
\text { Gatot }\end{array}$ & 375,264 & 9 & $0.5-1$ \\
\hline & 43 & \begin{tabular}{|l} 
Gatot \\
Gandaria
\end{tabular} & 793,493 & 18 & $0.5-1.5$ \\
\hline & 44 & $\begin{array}{l}\text { Gandara } \\
\text { Tempurung }\end{array}$ & $\begin{array}{r}438,824 \\
1252,390\end{array}$ & $\begin{array}{l}22 \\
21\end{array}$ & $\begin{array}{l}0.5-1 \\
0.5-1\end{array}$ \\
\hline & 45 & Anak Sungai Gardu & 493,745 & 11 & $0.5-1$ \\
\hline & 46 & Simpang Nangka & 1769,237 & 18 & $1-2$ \\
\hline & 47 & Gudang Hirang Kanan & 1511,260 & 17 & $1-2$ \\
\hline & 48 & Gudang Hirang Kiri & 2070,735 & 18 & $1-2$ \\
\hline & 49 & Banua Hanyar 3 & 1009,387 & 17 & $1-2$ \\
\hline & 50 & Darul Aman & 388,664 & 20 & $0.5-1$ \\
\hline Kecamatan Banjarmasin Barat & & & & & \\
\hline $\begin{array}{l}\text { Kecamatan Banjarmasin Barat } \\
\qquad 6\end{array}$ & 1 & Duyung & 1004,498 & 40 & 1.3 \\
\hline sungai & 2 & Bates Belitung Darat & 1351,590 & 16 & $1-1,5$ \\
\hline & $\frac{3}{4}$ & $\begin{array}{l}\text { Anak Pelambuan } \mathrm{Ka} 1 \\
\text { Anak Pelambuan } \mathrm{Ki} 1\end{array}$ & $\begin{array}{l}669,795 \\
681,436\end{array}$ & & $1-1,5$ \\
\hline & 5 & & $\begin{array}{r}681,436 \\
1505,277\end{array}$ & $\begin{array}{l}70 \\
50\end{array}$ & $1-1,5$ \\
\hline & 6 & $\begin{array}{l}\text { Pelambuan Besar } \\
\text { Sidomulyo } 2\end{array}$ & $\begin{array}{r}1505,277 \\
335,313\end{array}$ & $\begin{array}{l}50 \\
6\end{array}$ & $\frac{1-3}{0.5-1.5}$ \\
\hline & 7 & $\begin{array}{l}\text { Sidomulyo } 2 \\
\text { Bahara }\end{array}$ & 734,010 & 25 & $0.5-1.5$ \\
\hline & 8 & Sidomulyo 1 & 411,027 & 16 & $0.5-1.5$ \\
\hline & 9 & Belasung & 356,431 & 12 & $0.5-1$ \\
\hline & 10 & Antasan Raden & 588,194 & 25 & $0.5-1$ \\
\hline & 11 & Anak $\mathrm{Gg}_{\mathrm{g}}$ Saadah & 358,463 & 8 & $0.5-1$ \\
\hline & 12 & $G_{g}$ Saadah & 478.049 & 9 & $0.5-1$ \\
\hline & 13 & Saka Permaí & 2288,600 & 40 & $1-1,5$ \\
\hline & 14 & Anjir mulawarman & 1759.739 & 40 & $1-1,5$ \\
\hline & 15 & Barito & 11381,251 & 725 & $10-20$ \\
\hline & 16 & Taluk Kecil & 183,775 & 15 & $0.5-1.5$ \\
\hline & 17 & Diangkuci & 466,314 & 25 & $0.5 \cdot 1.5$ \\
\hline & $\begin{array}{l}18 \\
19\end{array}$ & $\begin{array}{l}\text { Rawa-Rawa } \\
\text { Anak Saka Permai }\end{array}$ & $\begin{array}{r}408,597 \\
60,900\end{array}$ & $\frac{18}{6}$ & $0.5-1.5$ \\
\hline & $\begin{array}{l}19 \\
20\end{array}$ & & $\begin{array}{l}60,900 \\
87,179\end{array}$ & $\begin{array}{l}6 \\
8\end{array}$ & $0.5-1$ \\
\hline & 21 & $\begin{array}{l}\text { Gg Kalimantan } \\
\text { Landas }\end{array}$ & $\begin{array}{r}87,179 \\
756,122\end{array}$ & $\frac{8}{25}$ & $\begin{array}{l}0.5-1 \\
0.5-1\end{array}$ \\
\hline & 22 & \begin{tabular}{|l} 
Landas \\
Anak Belitung
\end{tabular} & $\begin{array}{l}756,122 \\
308,662\end{array}$ & 10 & $\begin{array}{l}0.5-1 \\
0.5-1\end{array}$ \\
\hline & 23 & Gg AA & 280,796 & 5 & $\begin{array}{l}0.5-1 \\
0.5-1\end{array}$ \\
\hline & 24 & Cendrawasih & 612,726 & 10 & $0,50-1$ \\
\hline & 25 & Belitung Darat & 1322,676 & 15 & $0.5-1$ \\
\hline & 26 & Rawasari & 695,773 & 15 & $0.5-1$ \\
\hline & 27 & Jurung & 334,949 & 15 & $0.5-1$ \\
\hline & 28 & Anak Banyiur & 112,770 & 9 & $0.5-1$ \\
\hline & 29 & Anak Saka Sindawa & 234,893 & 22 & $0.5-1$ \\
\hline & 30 & Saka Sindawa & 1315,790 & 35 & $1-1,5$ \\
\hline & 31 & Banyiur & 1506,430 & 60 & $1-1,5$ \\
\hline & 32 & Bakantan & 778,143 & 25 & $1-1,5$ \\
\hline & 33 & Baguntin & 466,288 & 15 & $1-1,5$ \\
\hline & 34 & Jaranang & 303,300 & 8 & $1-1,5$ \\
\hline & 35 & Saka Benteng & 324,630 & 150 & $5-10$ \\
\hline & 36 & Saka Besar & 1135,126 & 15 & $1-1,5$ \\
\hline & 37 & Kartak & 21,861 & 4 & $0.5-1$ \\
\hline & 38 & Yapahut & 1085,523 & 52 & $0.5 \cdot 1$ \\
\hline & 39 & Gg Hikmah & 413,969 & 8 & $0.5-1$ \\
\hline & 40 & Gg Amal & 204,954 & 5 & $0.5=1$ \\
\hline & 41 & Simpang Belitung & 194,747 & 6 & $0.5-1.5$ \\
\hline & 42 & Simpang Anem & 433,605 & 12 & $0.5-1.5$ \\
\hline & 43 & Belitung Kecil & 156,040 & 6 & $0.5-1$ \\
\hline & 44 & Rawasari 14 & 850,675 & 12 & $0.5-1$ \\
\hline & 45 & Komp. Damai & 86,974 & 8 & $0.5-1$ \\
\hline & 46 & Gg Famili & 89,115 & 8 & $0.5-1$ \\
\hline
\end{tabular}




\begin{tabular}{|c|c|c|c|c|c|}
\hline Kecamatan & NO & Nama Sungai & $\begin{array}{l}\text { Panjang Sungai } \\
\text { (m) }\end{array}$ & $\begin{array}{c}\text { Lebar Sungai } \\
\text { (m) }\end{array}$ & $\begin{array}{l}\text { Kedalaman Sungai } \\
\text { (m) }\end{array}$ \\
\hline & & & & & \\
\hline \multirow{83}{*}{$\begin{array}{c}\text { Kecamatan Banjarmasin Selatan } \\
98 \\
\text { sungai }\end{array}$} & 1 & Handil Bujur Kiri & 837.559 & 25 & $1-1,5$ \\
\hline & 2 & Tallan & 1415,806 & 30 & $1-1,5$ \\
\hline & 3 & Anak Bagau Ka 2 Kanan & 1035,585 & 15 & $1-1,5$ \\
\hline & 4 & Handil Bujur & 2340,517 & 120 & $1-1,5$ \\
\hline & 5 & Pijung & 616.355 & 26 & $1-1,5$ \\
\hline & 6 & Anak Bagau Ki 1 & 289,148 & 8 & $1-1,5$ \\
\hline & 7 & Anak Bagau Ki 2 & 191,199 & 9 & $1-1,5$ \\
\hline & 8 & Anak Bagau Ka 1 & 268,804 & 4 & $1-1,5$ \\
\hline & 9 & Anak Kelayan Kecil Ka 2 & 1439,101 & 15 & $1-1,5$ \\
\hline & 10 & Anak Bagau Ki 3 & 1142,894 & 15 & $1-1,5$ \\
\hline & 11 & Anak Bagau Kini & 376,245 & 15 & $1-1,5$ \\
\hline & 12 & Anak Kelayan Kecil Ki 2 & 216,835 & 10 & $1-1,5$ \\
\hline & 13 & Saka Jawa & 1246,069 & 30 & $1-1,5$ \\
\hline & $\begin{array}{l}14 \\
15\end{array}$ & $\begin{array}{l}\text { Peradaban } \\
\text { Kelayan Besar }\end{array}$ & 1392,075 & 20 & $1-3$ \\
\hline & 16 & $\begin{array}{l}\text { Kelayan Besar } \\
\text { Anak Kelayan Besar Ki } 1\end{array}$ & $\begin{array}{r}2667,865 \\
241,966\end{array}$ & $\begin{array}{l}31 \\
14\end{array}$ & \\
\hline & 17 & Anak Tatah Belayung Ki 1 & 1001,583 & 10 & $\begin{array}{l}1-1,5 \\
1-1,5\end{array}$ \\
\hline & 18 & Anak Tatah Belayung Ka 1 & 136,966 & 8 & $1-1,5$ \\
\hline & 19 & Tatah Belayung & 4016,122 & 44 & $1-3$ \\
\hline & 20 & Anak Pemurus Ka 2 & 1203,351 & 50 & $0.5-1.5$ \\
\hline & 21 & Anak Pemurus Ka 1 & 539,010 & 11 & $0.5 \cdot 1.5$ \\
\hline & 22 & Gudang & 768,875 & 16 & 1.3 \\
\hline & 23 & Pemurus & 3328,513 & 58 & $1-3$ \\
\hline & $\begin{array}{l}24 \\
25\end{array}$ & \begin{tabular}{|l} 
Ahmad Yani \\
Gg Mekar Sari
\end{tabular} & 9922,277 & $\begin{array}{l}13 \\
20\end{array}$ & $\begin{array}{l}0.5-1.5 \\
0.5-1.5\end{array}$ \\
\hline & 26 & $\begin{array}{l}\text { Gg Mekar Sari } \\
\text { Anak Bahaur }\end{array}$ & $\begin{array}{l}444,334 \\
174,034\end{array}$ & $\begin{array}{c}20 \\
6\end{array}$ & $\begin{array}{c}0.5-1.5 \\
1-1,5\end{array}$ \\
\hline & 27 & Bahaur & 1308,646 & 25 & $1-3$ \\
\hline & 28 & Anak Basirih Ka 1 & 244,238 & 8 & $1-1,5$ \\
\hline & 29 & Anak Simpang Jelai Ka 2 & 297,986 & 15 & $1-1,5$ \\
\hline & 30 & Anak Simpang Jelai Ka 4 & 374,618 & 12 & $1-1,5$ \\
\hline & 31 & Anak Simpang Jelai Ki 1 & 195,135 & 15 & $1-1,5$ \\
\hline & 32 & Anak Simpang Jelai Ki 2 & 465,966 & 20 & $1-1,5$ \\
\hline & 33 & Anak Simpang Jelai Ka 1 & 388,279 & 15 & $1-1,5$ \\
\hline & $\begin{array}{l}34 \\
35\end{array}$ & Anak Simpang Jelai Ka 3 & 696,764 & 15 & $\begin{array}{l}1-1.5 \\
1-1.5\end{array}$ \\
\hline & $\begin{array}{l}35 \\
36\end{array}$ & Anak Handil Bamban Ka 1 & 136,386 & 9 & $1-1,5$ \\
\hline & $\begin{array}{l}36 \\
37\end{array}$ & $\begin{array}{l}\text { Anak Handil Bamban } \mathrm{Ki} 1 \\
\text { Anak Handil Bamban Ka } 2\end{array}$ & 204,541 & 8 & $\begin{array}{l}1-1,5 \\
1-1,5\end{array}$ \\
\hline & 38 & $\begin{array}{l}\text { Anak Handil Bamban Ka } 2 \\
\text { Handil Bamban }\end{array}$ & $\begin{array}{r}103,399 \\
1277,946\end{array}$ & $\begin{array}{c}7 \\
42\end{array}$ & $\begin{array}{l}1-1,5 \\
1-1,5\end{array}$ \\
\hline & 39 & $\begin{array}{l}\text { Handil Bamban } \\
\text { Basirih }\end{array}$ & $\begin{array}{l}1277,946 \\
4506,240\end{array}$ & 160 & $\begin{array}{c}1-1,5 \\
1-3\end{array}$ \\
\hline & 40 & Anak Runggun Ka 1 & 278,107 & 15 & $1-1,5$ \\
\hline & 41 & Anak Runggun Ki 1 & 536,815 & 15 & $1-1,5$ \\
\hline & 42 & Anak Runggun Ki 2 & 238,259 & 15 & $1-1,5$ \\
\hline & 43 & Anak Runggun Ka 2 & 310,197 & 15 & $1-1,5$ \\
\hline & 44 & Anak Runggun Ki 4 & 269,653 & 15 & $1-1,5$ \\
\hline & 45 & Anak Runggun Ki 5 & 122.055 & 15 & $1-1,5$ \\
\hline & $\begin{array}{l}46 \\
47\end{array}$ & Anak Runggun Ki 6 & 184,503 & 15 & $1-1,5$ \\
\hline & $\begin{array}{l}47 \\
48\end{array}$ & $\begin{array}{l}\text { Anak Runggun Ki } 7 \\
\text { Anak Runggun Ki } 8\end{array}$ & $\begin{array}{l}161,519 \\
215,119\end{array}$ & $\begin{array}{l}15 \\
15\end{array}$ & $\begin{array}{l}1-1,5 \\
1-1,5\end{array}$ \\
\hline & $\begin{array}{l}48 \\
49\end{array}$ & $\begin{array}{l}\text { Anak Runggun Ki } 8 \\
\text { Anak Runggun Ka } 3\end{array}$ & $\begin{array}{l}215,119 \\
367,965\end{array}$ & & $\begin{array}{l}1-1,5 \\
1-1,5\end{array}$ \\
\hline & 50 & $\begin{array}{l}\text { Anak Runggun Ka } 3 \\
\text { Anak Runggun Ka } 4\end{array}$ & 194,696 & 15 & $1-1,5$ \\
\hline & 51 & Runggun & 3057,827 & 38 & $1-1,5$ \\
\hline & 52 & Anak Runggun Ki 3 & 407,084 & 15 & $1-1,5$ \\
\hline & 53 & Antasan Bondan & 738,165 & 55 & $1-1,5$ \\
\hline & 54 & Bagau Kiri & 1054,631 & 55 & $1-1,5$ \\
\hline & 55 & Tatah Bangkal & 3769,687 & 56 & $1-1,5$ \\
\hline & 56 & Anak Saka Harang Ki 1 & 159.784 & 12 & $1-1,5$ \\
\hline & 57 & Anak Saka Harang Ki 2 & 255,780 & 12 & $1-1,5$ \\
\hline & $\begin{array}{l}58 \\
50\end{array}$ & Anak Saka Mangkuk Ki 4 & $\begin{array}{l}488,319 \\
511,735\end{array}$ & $\begin{array}{l}25 \\
15\end{array}$ & $\begin{array}{l}1-1,5 \\
1-1,5\end{array}$ \\
\hline & $\begin{array}{l}59 \\
60\end{array}$ & $\begin{array}{l}\text { Anak Saka Mangkuk Ki } 2 \\
\text { Saka Bangun }\end{array}$ & 451,613 & $\begin{array}{l}15 \\
15\end{array}$ & $\begin{array}{l}1-1,5 \\
1-3\end{array}$ \\
\hline & 61 & Saka Mangkuk & 4003,901 & 40 & $1-3$ \\
\hline & 62 & Anak Saka Mangkuk Ki 1 & 1217,234 & 20 & $1-1,5$ \\
\hline & 63 & Saka Harang & 3345,339 & 50 & $1-3$ \\
\hline & 64 & Anak Saka Harang Ki 3 & 410,328 & 15 & $1-1,5$ \\
\hline & 65 & Anak Saka Harang Ka 1 & 402,555 & 15 & $1-1,5$ \\
\hline & 66 & Anak Saka Harang Ka 2 & 349,477 & 15 & $1-1,5$ \\
\hline & 67 & Anak Saka Harang Ka 3 & 340,849 & 15 & $1-1,5$ \\
\hline & 68 & Anak Saka Harang Ka 4 & 396,344 & 15 & $1-1.5$ \\
\hline & 69 & Anak Perigi Ki 2 & 703,793 & 13 & $1-1,5$ \\
\hline & 70 & Mantuil & 905,655 & 15 & $1-1,5$ \\
\hline & 71 & Halinau & 2485,494 & 30 & $1-3$ \\
\hline & 72 & Simpang Jelai & 2205,458 & 55 & $1-3$ \\
\hline & 73 & Anak Perigi Ka 1 & 1336,787 & 30 & $1-1,5$ \\
\hline & 74 & Anak Kuin Kacil Ki 1 & 978,973 & 20 & $1-1.5$ \\
\hline & 75 & Anak Kuin Kacil ki 2 & 1008,836 & 25 & $1-1.5$ \\
\hline & 76 & Kuin Kacil & 4903,874 & 115 & $1-3$ \\
\hline & 77 & Anak Perigi Ki 1 & 1439,799 & 25 & $1-1.5$ \\
\hline & 78 & Perigi & 3283,102 & 50 & $1-3$ \\
\hline & 79 & Kelayan & 3708,718 & 90 & $1-3$ \\
\hline & 80 & Kelayan Kecil & 3452,858 & 85 & $1-3$ \\
\hline & 81 & Anak Kelayan Besar Ka 1 & 91,235 & 12 & $1-1,5$ \\
\hline & 82 & Anak Pijung Ka 1 & 626,090 & 25 & $1-1,5$ \\
\hline & 83 & Anak Pijung Ka 2 & 294,106 & 20 & $1-1.5$ \\
\hline & 84 & Anak Kelayan Kecil Ki 1 & 532,410 & 9 & $1-1,5$ \\
\hline & 85 & Anak Pemurus Ki 2 & 122,828 & 7 & $1-1,5$ \\
\hline & 86 & Buaya & 237,274 & 18 & $1-1,5$ \\
\hline & 87 & Pangilun & 820,294 & 12 & $1-1.5$ \\
\hline & 88 & Kembang Kuning & 352,095 & 9 & $1-1,5$ \\
\hline
\end{tabular}




\begin{tabular}{|c|c|c|c|c|c|}
\hline Kecamatan & No & Nama Sungai & $\begin{array}{c}\text { Panjang Sungai } \\
\text { (m) }\end{array}$ & $\begin{array}{l}\text { Lebar Sungai } \\
(m)\end{array}$ & $\begin{array}{c}\text { Kedalaman Sungai } \\
(m)\end{array}$ \\
\hline & 89 & Muning & 145,706 & 8 & $1-1,5$ \\
\hline & 90 & Anak Bagau Ka 2 & 1352,063 & 25 & $1-1,5$ \\
\hline & 91 & Bagau & 4436,257 & 65 & 1.3 \\
\hline & 92 & Anak Panggal Ka 2 & 94,635 & 10 & $1-1,5$ \\
\hline & 93 & Anak Panggal Ki 1 & 428,967 & 15 & $1-1,5$ \\
\hline & 94 & Panggal & 1340,183 & 24 & $1-3$ \\
\hline & 95 & Anak Panggal Ka 1 & 275,823 & 11 & $1-1,5$ \\
\hline & 96 & Anak Kelayan Kecil Ka 1 & 894,098 & 11 & $1-1,5$ \\
\hline & 97 & Anak Pemurus $\mathrm{Ki} 1$ & 676,734 & 12 & $1-1,5$ \\
\hline & 98 & Pahalau & 886,683 & 20 & $1-1,5$ \\
\hline & & & & & \\
\hline Kecamatan Banjarmasin Tengah & 1 & Parit & 403,595 & 10 & $0,5 \cdot 1$ \\
\hline 26 & 2 & Sifa & 404,445 & 12 & $0.5-1$ \\
\hline sungai & 3 & KP Tendean & 267,571 & 6 & $0,5-1$ \\
\hline & 4 & Tatas & 694,668 & 20 & $0,5-1$ \\
\hline & 5 & Pekapuran & 1516,905 & 60 & $0,5-1$ \\
\hline & 6 & Pasar Kamboja & 178,868 & 8 & $0,5-1$ \\
\hline & 7 & Pacinan & 1392,751 & 20 & 1.3 \\
\hline & 8 & J1 Bali & 653,916 & 14 & $0,5-1$ \\
\hline & 9 & Benawa & 658,540 & 7 & $0,5 \cdot 1$ \\
\hline & 10 & Meratus & 473,553 & 14 & $0,5 \cdot 1$ \\
\hline & 11 & Skip lama & 421,803 & 10 & $0,5 \cdot 1$ \\
\hline & 12 & Kerokan & 1139,085 & 40 & $0.5 \cdot 1$ \\
\hline & 13 & Teluk Dalam & 2385,502 & 18 & $0,5-1$ \\
\hline & 14 & Pasar Rambai & 147,711 & 5 & $0,5 \cdot 1$ \\
\hline & 15 & Telawang & 919,269 & 14 & $10 \cdot 15$ \\
\hline & 16 & Martapura & 23425,030 & 220 & $0,5-1$ \\
\hline & 17 & Salatiga & 382,488 & 14 & $0,5-1$ \\
\hline & 18 & Seberang Mesjid 1a & 137,989 & 6 & $0,5-1$ \\
\hline & 19 & Seberang Mesjid 1 & 75,750 & 8 & $0,5-1$ \\
\hline & 20 & Telok Sento & 484,244 & 12 & $0.5-1$ \\
\hline & 21 & Henoi & 550,612 & 14 & $0,5-1$ \\
\hline & 22 & Gg Melati & 216,511 & 8 & $0,5-1$ \\
\hline & 23 & Komp. Sederhana & 84,890 & 10 & $0,5-1$ \\
\hline & 24 & Getek & 299,710 & 7 & $0,5-1$ \\
\hline & 25 & Anak JI Bali & 106,960 & 8 & $0,5-1$ \\
\hline & 26 & Gg Menara & 96,541 & 5 & $0.5-1.5$ \\
\hline & \multirow{2}{*}{\multicolumn{2}{|c|}{$\begin{array}{l}\text { TOTAL PANJANG SUNGAI } \\
\text { TOTAL SUNGAI }\end{array}$}} & $296.864,02$ & meter & \\
\hline & & & 290 & sungai & \\
\hline
\end{tabular}

It is not about how many rivers are, but the important thing is that when the tide comes, the rivers and canals can contain the tide to its maximum level so that Banjarmasin is safe from flooding. However, the numbers of rivers and the documentation are administratively needed by the government to make policies based on facts and to make sure that there are no uncertain aspects. These documents are also important assets of the Banjarmasin City Government.Related to the constraints experienced by the Public Works and Public Housing (PUPR) Office of River Field to apply the provisions of the Regulation related to the river, each application must experience obstacles. One of the obstacles is that the rivers that are recorded have housing or building certificates. When the Public Works and Public Housing (PUPR) Office Department of River Field wants to collect the data and manage the rivers, these certificates make the process difficult. This problem also makes the Public Works and Public Housing (PUPR) Office solve the problem in a middle way, which the Public Works and Public Housing (PUPR) Office requested that the river does not be closed and for the other party to use and have the river as it is stated in certificates.

Another disadvantage of the rivers in Banjarmasin is that there are no certified rivers. In the future, the Public Works and Public Housing (PUPR) Office of River Field wants to certify the rivers in Banjarmasin. Until now, the rivers in the city of Banjarmasin are only determined through the Decree of the Mayor of Banjarmasin, 
starting in 2009 when the River Field was still a separate Service that was originally established in 2009, namely under the name of the Office of River Management and Drainage. [xiv]In 2011 based on the Decree of the Mayor of Banjarmasin No. 158 of 2011 on the Determination of Rivers as Public Facilities and Assets of the City Government, there were 102 rivers in Banjarmasin City. On the Decision of the Mayor of Banjarmasin No. 158 in 2011, the collection of rivers increased to 102 and the latest data on The Mayor's Decree Banjarmasin 647 of 2020, the collection of rivers increased to 290 rivers. This data will become the reference of the Public Works and Public Housing (PUPR) Office of River Field to certify the rivers in the city of Banjarmasin. If not determined by the certificate, the collection and management of the river will continue to be hampered. With the certification of the river, it is expected that later the utilization and management of the river becomes the authority of the Public Works and Public Housing (PUPR) Office of River Field. The community is welcome to use the river, but before the process must be allowed by the Public Works and Public Housing (PUPR) Office of River Field.

\subsection{Banjarmasin City Government Policy}

To suppress the reduced water capacity due to construction activities, the Banjarmasin city regulation No. 14 of 2009 on Stage Building aims to control development to be following the Banjarmasin City Regional Spatial Plan needs to be controlled by space utilization. In addition, it is intended that buildings and houses can ensure the safety and comfort of residents must be held in an orderly manner, realized following the environmental conditions of Banjarmasin which has tidal waves, then the construction is carried out with the construction of stage buildings.Regulation No. 14 of 2009 consists only of IX chapters and 13 Articles. Therefore, the substance of this regulation only regulates a small part of the building problem that should be incorporated into the IMB (Building Permit). This material content is more regulated about the obligation to build buildings concerning water catchment. But this regulation also returns it to be included in the requirements of the building permit by government/IMB. This is as can be known through Article 4:

(1) Every building that is erected construction is a stage building and certain buildings are characterized by Banjar cultural areas.

(2) The form of stilt buildings and certain buildings characterized by Banjar culture can be concrete construction or wood construction.

(3) The obligation to build with the construction of a stage building by not eliminating the water catchment function is included in the provisions of the building permit/IMB.

(4) The technical requirements of the stage building are further regulated by the Mayor's Regulation.

Although there is already a stage building that requires the entire building to use a foundation that provides a cavity for water catchment so as not to cause standing water, in its implementation this regulation is difficult to apply. If you look at the development in the Banjarmasin, especially the construction of shophouses, most 
buildings turn off the function of water catchment, and somehow this is another problem that is faced in regulating and arranging rivers in Banjarmasin.

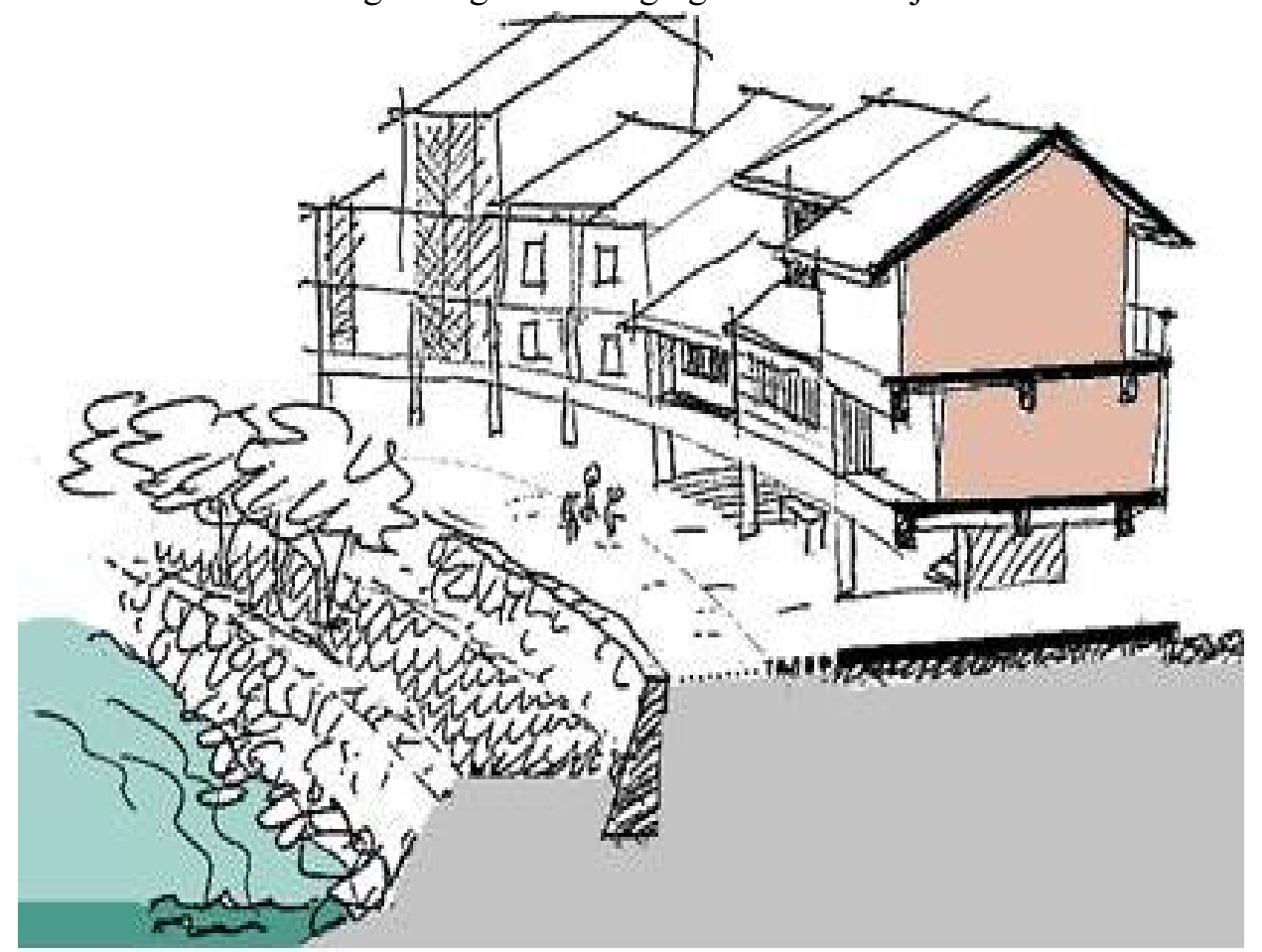

Stage House Sketch

\subsection{River Normalization Task Force}

As a result of the occurrence of major floods that almost covered the entire Province of South Kalimantan as mentioned above. The city of Banjarmasin was also severely affected. The great South Borneo flood has paralyzed the social and economic activity of its citizens triggered again by the malfunction of rivers and canals in the Banjarmasin city area, so the Mayor immediately took policy steps by forming a Task Force.The River Task Force in the PUPR Office of River Field does not exist, but in the Environment Agency, there is such a thing as the River Cleanliness Task Force. At the beginning of the flood in the city of Banjarmasin, there is such a thing as the River Normalization Task Force, but now it does not exist, it is expected that in the future the task force will be formed again if the river normalization program post-flood. The task force consists of various elements, from the community, the government, prosecutors, the police.[xv]

\section{Arrangement of The River Through Community Culture}

The lives of the people of Banjarmasin city are not separated from the Barito River and Martapura river and its tributaries. The close relationship between society and the river has been proposed by Elizabeth P. Anderson et.al as stated by River flows connect people, places, and other forms of life, inspiring and sustaining diverse cultural beliefs, values, and ways of life. The concept of environmental flows provides a 
framework for improving understanding of relationships between river flows and people, and for supporting those that are mutually beneficial. [xvi]Based on history perspective, the rivers in Banjarmasin was once played a strategic role in trade traffic between islands, because it was located at the confluence between the Barito river and the vast and deep Martapura River. Located $22 \mathrm{~km}$ from the Java Sea, the rivers can certainly be navigable by large ships so that Ocean ships can dock to the city of Banjarmasin. The River became an inseparable part of the city of Banjarmasin so that Banjarmasin earned the nickname "city of a thousand rivers" even though the river flowing in Banjarmasin was not up to a thousand. The river became the main activity container of ancient society until now, especially in the field of trade and transportation.

The rivers that divide the city are sought as economic magnets, especially tourism. (History of Banjarmasin City).As Elizabeth P. Anderson said: In 2018, scientists, river conservationists, and water managers revisited the Brisbane Declaration and Global Action Agenda of 2007. In the decade between the first and second declarations, the environmental flow community had come to appreciate that "social and cultural dimensions of environmental flow management warrant far more attention" (Arthington et al.,2018, p. 2). Thus, a significant new element of the 2018 Declaration and Global Action Agenda is the emphasis given to "full and equal participation for people of all cultures, and respect for their rights, responsibilities, and systems of governance in environmental water decisions" (Arthington et al.,2018, p. 12).https://onlinelibrary.wiley.com/doi/full/10.1002/wat2.1381The culture of the river in Banjarmasin appeared with its citizen even before the newly made regulations. The origin of Banjarmasin itself is from the river. To implement the rivers acquisition, the government should not implement it carelessly and must think about where the citizens will be moved and also how the citizens work after the acquisition process. [xvii] To change the mindset of the community to make the rivers a center of community activities, the Public Works and Public Housing (PUPR) Office of River Field every year conducts socialization of river management and drainage in collaboration with the Drainage Field.

In the socialization, education about how important rivers are is usually carried out and this socialization is done every year in each sub-district. But in the last two years, this could not be done because of the pandemic that is sweeping around the world, especially in the city of Banjarmasin, South Kalimantan province. Since pandemic situation needs people to maintain their distance, socialization cannot be conducted.The socialization is a step from the PUPR Office of River Field to change the mindset of the people of Banjarmasin that the river is common property, including in infrastructure changes, it used to start with the construction of siring, in the last three years the infrastructure development carried out was the manufacture of stairs, such as those built in the Kuin area. The concept also holds the banks and sizzles, so that the community can interact directly with the river and the community grows a sense of 
belonging to the river. One of the other steps in resuscitating the mindset of the community to realize the importance of the river is "the mud lift race", which involves all the people who participate in the race in terms of lifting as much mud in the river, and the excitement of the race is effective in overcoming the mud waste in the river. But at this time, the race is not implemented because of confusion over the land to dispose of the mud. In these 2-3 years, the Public Works and Public Housing (PUPR) Office Department of River Affairs has requested mud disposal land since it cannot be careless in removing mud with soil conditions in the city of Barjarmasin is in the form of a swamp and if stacked in the existing area, it even becomes a burden of water so it should be put in a special area.

However, the development of the lives of the citizens of the city of Banjarmasin whose economic center began to change from the rivers to the mainland makes the people think that the river is no longer the center of community activities but only a waste dump and a garbage disposal place.Among the causes that make the river disappear or become shallow rivers so that the function of the river becomes not maximal is because of the behavior of the residents of Banjarmasin itself who always make the river as a landfill for their garbage. The habit of dumping garbage into the river has led to a community culture that needs to be straightened out, and the regional regulations about waste and garbage are made from this perspective.



The river becomes the lifeblood of the lower society

The management of the waste and garbage in Banjarmasin City is based on The Banjarmasin City Regional Regulation No. 21 of 2011 concerning the Management of Waste and Garbage/Cleanliness and Park. Previously, the management of the waste and garbage was based on The Banjarmasin City Regional Regulation No. 10 of 2009 on Waste Management and Sanitation and Hygiene Levy. However, after one year of implementation based on the results of the evaluation, several materials need to be reviewed for changes. The purpose of this regulation is the framework of the implementation of cleanliness to create a clean, beautiful, and harmonious Banjarmasin 
City, there needs to be certainty and clarity of the arrangement of the division of authority between the Local Government and the participation of the community and the business world. In addition, for the creation of a harmonious balance between open spatial arrangements, green urban governance of Banjarmasin City that can meet the requirements as an environmentally minded, beautiful, harmonious, and sustainable city and maintain the development results that have been achieved and in the framework of efforts to overcome the problem of air conditioning in the area of Banjarmasin City.This regulation also actually plays a role in river management, because this regulation contains a prohibition not to dirty the rivers by throwing garbage or putting some waste.

Article 34 paragraph (1) letter $d$ regulates:

(1) Everyone is prohibited:

1. Dumping trash in the streets,

2. water channel (drainage),

3. in the river

(2) Every business entity is prohibited:

1. Dumping trash in the streets,

2. aqueducts (drainage),

3. in the river

(3) Every street vendor is prohibited from dumping garbage or leftovers into the streets, waterways (drainage), in the River.

The formation of this regulation does not seem to be careful, this can be seen in the absence of sanctions given when violating the provisions of the prohibition stipulated in article 34. The criminal provisions stipulated in article 38 mention the reference of articles that have absolutely nothing to do. Article 38 reads:

(1) Whoever commits a violation of Article 31 paragraph (1) except letter $\mathrm{k}$ and paragraph (2) unless the letter e is threatened with confinement for a maximum of 3 (three) months or as much as Rp.5,000,000.00 (Five Million Rupiah).

(2) Anyone who violates the provisions of Article 31 paragraph (1) letter $\mathrm{k}$ and paragraph (2) letter e is threatened with imprisonment for a maximum of 3 (three) months or a fine of paying a replacement tree as much as 100 (one hundred) trees of the same type and size of 1 (one) tree that was cut down or fined as much as Rp.50,000,000.00 (Fifty Million Rupiah).

(3) The criminal acts referred to in paragraph (1) and paragraph (2) of this Article are violations.

(4) The fine as referred to in paragraph (1) and paragraph (2) is deposited in the Regional Treasury.

The referenced article is Article 31. Article 31 reads Article 31 cooperation between local governments as referred to by Article 27 as stated in the Joint Decree of the Regional Head after obtaining the Governor's Approval. 


\section{CONCLUSION}

Based on the geographical condition of Banjarmasin, rivers and canals should be very important for Banjarmasin as a way to avoid flooding. Therefore, it is necessary to arrange rivers and canals in the city of Banjarmasin comprehensively. It can't be done partially. The river arrangement includes regulatory, institutional, and community development aspects in the vicinity. The development of the city of Banjarmasin from the point of view of city development must start from the rivers.

\section{ACKNOWLEDGMENTS}

Thanks are conveyed to all parties who have helped in completing this research, especially related agencies and stakeholders who provide information in interviews. In addition, thanks were also conveyed to the Research and Community Service Institute of Lambung Mangkurat University which provided funding in this study based on Lecturer Program Must Research with PNBP University Financing Scheme in Lambung Mangkurat University Environment Fiscal Year 2021 Cluster Madya Number: 009. 136/UN8.2/PL/2021.

\section{REFERENCES}

[1] Michelle Rebekah, Anak Agung Banyu Perwita, Water Security in the Meleong River and Regional Stability in Southeast Asia, AEGIS, Vol 2 No. 1, September 2019, h. 2636, 2015.

[2] The ASEAN Post Team, Southeast Asia's rivers Under Threat, December 12, 2019.

[3] Evans, A.E., et.al Water Quality: Assessment of the Current Situation in Asia, Journal United Nation University, Institute for Water, Environmental and Helth (2021)

[4] Reza Banakar and Max Travers (eds), Law and Society Theory, (Hart Publishing, 2013), p. 78.

[5] Terry Hutchinson, Researching and Writing in Law, Lawbook Co \& A Thomson Company, NSW, 2002

[6] Suteki, Legal Research Methodology, Philosophy of Theory and Practice, p. 157

[7] Geoffrey E. Petts, River Regulation, Environmental Geology, 1999 edition.

[8] Golubev, G. N., and Biswas, A. K. (eds), 1985. Large Scale Water Transfers: Emerging Environmental and Social Experiences. Oxford Tycooly, United Nations Environment Program, 158pp.

[9] The importance of structuring rivers through institutions can be seen in an old paper from Irving K. Fox entitled Institutions for Water Management in a Changing World, Natural Resources Journal, Volume 16 Issue 4 Symposium on Water Resources Management in a Changing World Fall 1976.

[10] Mathew Kurian, Institutions for integrated water resources management in river basins: A synthesis of IWNI Research, February 2004

[11] Interview with The Head of River Department pupr office banjarmasin Hizbulwathoni, S.T. on August 16, 2021 
[12] In 2011 based on the Decree of the Mayor of Banjarmasin No. 158 of 2011 on the Determination of Rivers as Public Facilities and Assets of the City Government, there were 102 rivers in Banjarmasin City.

[13] In 2011 based on the Decree of the Mayor of Banjarmasin No. 158 of 2011 on the Determination of Rivers as Public Facilities and Assets of the City Government, there were 102 rivers in Banjarmasin City.

[14] Interview with The Head of River Department pupr office banjarmasin Hizbulwathoni, S.T. on August 16, 2021

[15] Interview with The Head of River Department pupr office banjarmasin Hizbulwathoni, S.T. on August 16, 2021

[16] https://onlinelibrary.wiley.com/action/doSearch?ContribAuthorStored=Anderson $\% 2 \mathrm{C}+\mathrm{E}$ lizabeth+P Elizabeth P. Anderson.

[17] M. Hadin Muhjad, Environmental Law, An Introduction to the Indonesian Context, Genta Publishing, Yogyakarta, 2015. p.118). 